\title{
Motif dan Kepuasan Followers Dalam Mengikuti Akun Fahrida Inayati @fahrida26 di Instagram
}

\author{
Azalia Iqony \\ azaliaiqony@gmail.com
}

\begin{abstract}
Abstrak
Penelitian ini dilakukan untuk mengetahui motif dan kepuasan followers dalam mengikuti akun Fahrida Inayati @fahrida26 di instagram. Penelitian ini menggunakan teori uses and gratification dengan tiga indikator yaitu sharing communication, social escape dan information. Penelitian ini menggunakan metode online survey dengan pendekatan kuantitatif dan jenis penelitian Eksplanatif. Sampel penelitian adalah followers akun @fahrida26 berusia 18-21 tahun, yang merupakan target usia dari akun Fahrida Inayati. Pada online survey peneliti menggunakan sebagai data pengukuran skala likert. Dari hasil penelitian ini ditemukan bahwa followers akun @ fahrida26 mendapatkan kepuasan yang tertinggi adalah indikator sharing communication.
\end{abstract}

Kata-kata Kunci: @fahrida26, Fahrida Inayati, Motif, Kepuasan, Media Sosial Instagram

\section{(A) Pendahuluan}

Teori Uses and Gratification yang dikemukakan Herbert Blumer dan Elihu Katz menjelaskan bahwa pemirsa memiliki segala kuasa dalam pemilihan informasi. Pengguna media memainkan peran aktif untuk memilih dan menggunakan media tersebut, serta lebih menekankan pada pendekatan manusiawi dalam melihat media massa, manusia mempunyai otonomi, wewenang untuk memperlakukan media. Blumer dan Katz percaya bahwa ada banyak alasan atau motif khalayak untuk menggunakan media (Nurudin 2013, p.192).

Dalam teori ini, followers memiliki hak untuk memperlakukan media secara spesifik. Khalayak aktif ini bebas berinteraksi dengan media dan menginterpretasi pesan yang diterima. Pendekatan uses and gratifications menempatkan hubungan dari antara kepuasan akan kebutuhan dan pilihan media oleh khalayak dengan jelas. Ini menegaskan bahwa kebutuhan khalayak mempengaruhi media apa yang mereka pilih, bagaimana mereka memilih media dan kepuasan yang diberikan oleh media (Nurudin 2013 p.192).

Internet sebagai new media pada prinsipnya dapat dimanfaatkan oleh siapapun untuk kepentingan apapun, new media merupakan istilah yang digunakan untuk berbagai teknologi komunikasi yang dimungkinkan dengan digitalisasi dan ketersedianya yang luas untuk penggunaan pribadi sebagai alat komunikasi (Mc Quail, 2011, p.548).

Media sosial instagram yang selama ini melekat dan sering diakses pada kehidupan sehari-hari yang di nikmati ternyata juga dapat mempengaruhi dalam kehidupan ataupun didalam gaya hidup followers tersebut. Apalagi ketika followers sudah menyukai atau fans terhadap selebgram, maka selebgram atau selebgram yang disukai tidak akan jauh dari gaya hidupnya.

Selebgram berasal dari kata selebriti dan Instagram. Selebriti sendiri adalah seorang publik figur atau seseorang yang banyak dikenal oleh publik. Seseorang dikatakan sebagai selebgram ketika dirinya memiliki banyak followers atau pengikut di Instagram. Ada beberapa selebgram yang memiliki pengikut di Instagram lebih dari 100.000 akun pengguna, dan memiliki latar belakang kehidupan yang berbeda-beda. 
Fahrida Inayati yang lahir di Kudus, 26 Agustus 1998 merupakan seorang selebriti sosial media Instagram atau biasa disebut selebgram. Akun yang dipakai Fahrida Inayati ialah @fahrida26. Estimasi penghasilan setiap 1 post Instagram ialah kisaran $\$ 106,5$ - \$177,5 atau setara dengan Rp1.499.621,18 - Rp2.499.368,63.

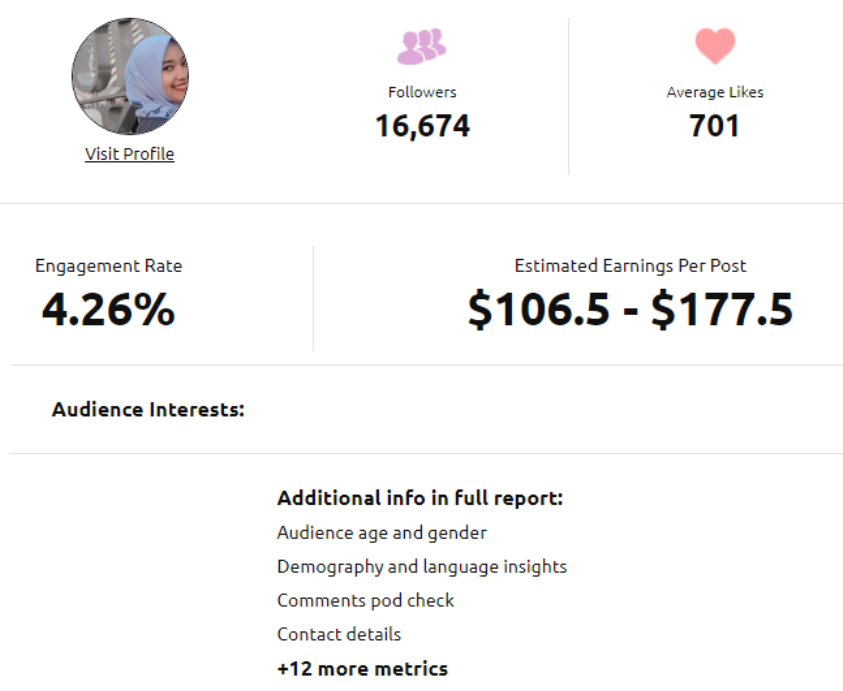

Gambar 1. Estimasi penghasilan akun @ fahrida26 setiap 1 post Instagram

Fahrida Inayati juga aktif dalam media sosial lain seperti Facebook dan Twitter. Fahrida Inayati yang dikenal sebagai selebgram di media sosial instagram yang mengekspos gaya hidup perempuan anggun.

Remaja adalah suatu masa di mana individu berkembang dari saat pertama kali ia menunjukkan tanda-tanda seksual sekundernya sampai saat ia mencapai kematangan seksual (Sarwono, 2011), semua aspek perkembangan dalam masa remaja secara global berlangsung antara umur 12-21 tahun, dengan pembagian usia 12-15 tahun adalah masa remaja awal, 15-18 tahun adalah masa remaja pertengahan, 18-21 tahun adalah masa remaja akhir (Monks, 2009). Penggunaan media sosial instagram juga menimbulkan fenomena tersendiri dikalangan penggunanya para followers akhir berusia 18-21.

Dapat dilihat dari latar belakang diatas, peneliti bertujuan untuk meneliti followers Instagram di akun@fahrida26. Penelitian ini akan melihat bagaimana motif dan kepuasan followers dalam mengikutiakun@fahrida26 di Instagram.

\section{(B) Tinjauan Pustaka}

\section{(1) Teori Uses and Gratifications}

Khalayak pada dasarnya menggunakan media massa berdasarkan motif-motif tertentu. Media dianggap berusaha memenuhi motif khalayak. Jika motif ini terpenuhi maka kebutuhan khalayak akan terpenuhi. Pada akhirnya, media yang mampu memenuhi kebutuhan khalayak disebut media efektif (Kriyantono, 2010, p. 207-208).

\section{(2) Uses and Gratifications New Media}

Dalam penelitian ini merupakan salah satu daya tarik dari media baru: interaktif media semakin mengaburkan batas antara pengirim dan penerima dari pesan tersebut menurut (Ruggiero, 2000, p.15). 


\section{(3) Gratification Sought and Gratification Obtained (Konsep Mengukur Kepuasan: Kepuasan yang dicari dan diperoleh)}

Menurut Philip Palmgreen menggunakan konsep berpikir bahwa khalayak memilih media oleh motif-motif tertentu. Namun, Philip juga meneliti apakah motif-motif tersebut telah dipenuhi oleh media yang dipilih khalayak tersebut. Halini dapat dikatakan dengan nilai ekspektasi (expectanty value) yang muncul dari khalayak media tertentu (McQuail, 20011). Peneliti dapat mengetahui kepuasan khalayak berdasarkan kesenjangan antara GS dan GO. Dengan kata lain, kesenjangan kepuasan (discrepancy gratifications) adalah perbedaan perolehan kepuasan yang terjadi antara skor GS dan GO dalam mengonsumsi media tertentu. Semakin kecil discrepancy-nya, semakin memuaskan media tersebut.

\section{(4) New Media}

Menurut (McQuail 2011, p.43) menjelaskan bahwa "Media Baru atau New Media adalah berbagai perangkat teknologi komunikasi yang berbagi ciri yang sama yang mana selain baru dimungkinkan dengan digitalisasi dan ketersediaannya yang luas untuk penggunaan pribadi sebagai alat komunikasi", ciri utama media baru adalah adanya saling keterhubungan, aksesnya terhadap khalayak individu sebagai penerima maupun pengirim pesan, interaktivitasnya, kegunaan yang beragam sebagai karakter yang terbuka, dan sifatnya yang ada di mana-mana.

\section{(5) Media Sosial}

Media online yang mendukung interaksi sosial. Sosial media menggunakan teknologi berbasis web yang mengubah komunikasi menjadi dialog interaktif. Beberapa situs media sosial yang populer sekarang ini antara lain : Blog, Twitter, Facebook, Instagram, Path, dan Wikipedia. Definisi lain dari sosial media juga di jelaskan oleh Van Dijk media sosial adalah platform media yang memfokuskan pada eksistensi pengguna yang memfasilitasi mereka dalam beraktivitas maupun berkolaborasi. Karena itu, media sosial dapat dilihat sebagai fasilitator online yang menguatkan hubungan antar pengguna sekaligus sebagai sebuah ikatan sosial (Nasrullah, 2015 p.11).

\section{(6) Instagram}

Instagram adalah sebuah aplikasi yang digunakan untuk membagi-bagikan foto dan video. Instagram sendiri masih merupakan bagian dari Facebook yang memungkinkan teman Facebook kita mengikuti akun Instagram kita. Makin populernya Instagram sebagai aplikasi yang digunakan untuk membagi foto membuat banyak pengguna yang terjun ke bisnis online turut mempromosikan produk-produknya lewat media sosial Instagram (M Nisrina, 2015, p.137).

\section{(7) Celebrity Endorsement}

Menurut Shimp (2010: 450, dalam Ash-shiddieq, 2014), "Celebrity Endorsement memanfaatkan seorang artis, entertainer, atlet dan publik figure yang mana banyak diketahui oleh orang banyak untuk keberhasilan dibidangnya masing- masing dari bidang yang didukung". Sementara itu, celebrity endorser dalam Instagram atau biasa dikenal dengan "selebgram" merupakan sebutan bagi para mereka yang dipercaya untuk membawakan produk-produk yang dijual secara online melalui akun Instagram.

\section{(C) Metode}




\section{(1) Konseptualisasi Penelitian}

Penelitian ini menggunakan definisi konseptual motif dan kepuasan. Gratification Sought atau yang biasa diartikan dengan motif adalah dorongan yang ada di dalam diri seseorang untuk melakukan suatu aktifitas. Motif yang merupakan kepuasan yang dicari seseorang dalam menggunakan media tertentu (McQuail, 2011, p.74). Gratifications Obtained adalah kepuasan yang nyata yang diperoleh seseorang setelah mengkonsumsi suatu jenis media tertentu. Menurut (Palmgreen, 1985, p.27).

Peneliti menggunakan variabel yang berkaitan dengan motif (Gratification Sought) individu dalam akun @fahrida26 di Instagram, yaitu:

\section{(a) Berbagi (Sharing Communication)}

(1) Saya mengikuti Instagram @fahrida26 untuk melihat foto dan video yang di bagikan @ fahrida26.

(2) Saya mengikuti Instagram @fahrida26 untuk memberikan komentar dan like pada postigan@fahrida26.

(3) Saya mengikuti Instagram @fahrida26 untuk membagikan foto dan video kehidupan sehari-hari @fahrida26 denganfollowers saya.

(4) Saya mengikuti Instagram @fahrida26 untuk berinteraksi dengan followers yang memiliki hoby yang sama dengan saya.

(5) Saya mengikuti Instagram @fahrida26 untuk menerima informasi dariakun @ fahrida26.

(6) Saya mengikuti Instagram @fahrida26 untuk saling berbagi informasidengan followers yang memiliki hoby yang sama dengan saya.

(7) Saya mengikuti akun @ fahrida26 untuk mendapatkan kesenangan.

(8) Saya mengikuti Instagram @fahrida26 untuk berkomunikasi dengan followers @ fahrida26 yang lainnya.

(9) Saya mengikuti akun@fahrida26 untuk mengisi waktu luang.

\section{(b) Sosial Pelarian (Social Escape)}

(1) Saya mengikuti Instagram @ fahrida26 untuk mengikutiperkembangan zaman.

(2) Saya mengikuti Instagram @fahrida26 untuk mendapatkan respon daripengguna lain terhadap postingan @fahrida26 yang saya sudah bagikan.

(3) Saya mengikuti Instagram @fahrida26 dengan menggunakan nama samaran bukan dengan nama yang sebenarnya.

(4) Saya mengikuti Instagram @ fahrida26 untuk menghilangkan rasa kesepian saya.

(5) Saya mengikuti Instagram @fahrida26 karena postingan yang diunggah @fahrida26 sangat menarik perhatian saya.

(6) Saya mengikuti Instagram @fahrida26 untuk terlihat istimewa jika komentar saya ditanggapi followers lain.

(c) Informasi (information)

(1) Saya mengikuti Instagram @fahrida26 untuk mengetahui informasi yang sedang viral. (Informasi)

(2) Saya mengikuti Instagram @ fahrida26 untuk perbaharui informasi

(3) Saya menggunakan hastag (\#) \#fahrida26 atau \#fahridainayati untuk mencari informasiyang lebih spesifik.

(4) Saya mengikuti Instagram @fahrida26 untuk mengikuti trend terbaru @fahrida26 di Instagram. 
Sementara untuk kategori kepuasan yang nyata, yang diperoleh individu atas terpenuhinya kebutuhan setelah mengkonsumsi media, hal yang diperoleh (Gratifications Obtained) dalam penelitian ini, yaitu :

\section{(a) Berbagi (Sharing Communication)}

(1) Setelah saya mengikuti akun @fahrida26 saya merasa senang melihat foto dan video yang dibagikan @ fahrida26.

(2) Setelah saya mengikuti akun@fahrida26 saya merasa bebas memberikan komentar dan like pada postingan @ fahrida26.

(3) Setelah saya mengikuti akun @fahrida26 saya merasa bebas membagikan foto dan video sehari-hari @ fahrida26 kepada followers saya.

(4) Setelah saya mengikuti akun @fahrida26 saya merasa senang berinteraksi dangan followers@ @ahrida26 yang memiliki hoby yang sama dengan saya.

(5) Setelah saya mengikuti akun @fahrida26 saya merasa senangmenerima informasi dari postingan@fahrida26.

(6) Setelah saya mengikuti akun @fahrida26 saya merasa senang membagikan informasi @ fahrida26 dengan followers lain yang memiliki hoby yang sama dengan saya.

(7) Setelah saya mengikuti akun @fahrida26 saya merasa senang menjadi followers @ fahrida26 di instagram.

(8) Setelah saya mengikuti akun @fahrida26 saya merasa senang dapat berkomunikasi denganfollowers @fahrida26yang lain.

(9) Setelah saya mengikuti akun @ fahrida26 saya merasa senang menghabiskan waktu luang.

(b) Sosial Pelarian (Social Escape)

(1) Setelah saya mengikuti akun @fahrida26 saya merasa senangmengikuti perkembangan zaman.

(2) Setelah saya mengikuti akun @fahrida26 saya merasa bebas jika postingan @fahrida26 yang saya bagikan direspon oleh penggunalain.

(3) Setelah saya mengikuti akun @fahrida26 saya merasa bebas mengakses menggunakan akun dengan nama yang berbeda.

(4) Setelah saya mengikuti akun @ fahrida26 saya tidak merasa kesepian.

(5) Setelah saya mengikuti akun @ fahrida26 saya merasa tertarik melihat setaip postingan yang diunggah sehari-hari.

(6) Setelah saya mengikuti akun @ fahrida26 saya merasa istimewa dan penting jika ada komentar saya ditanggapi followers lain.

(c) Informasi (information)

(1) Setelah saya mengikuti akun @fahrida26 saya merasa senangmengetahui informasi yang viral melalui akun @ fahrida26.

(2) Setelah saya mengikuti akun @fahrida26 saya dapat perbaharui informasi terbaru @ fahrida26.

(3) Setelah saya mengikuti akun @fahrida26 saya dapat mengetahui informasi menggunakan hastag (\#) @fahrida26 lebih spesifik.

(4) Setelah saya mengikuti akun@fahrida26 saya senang mengikuti trend.

\section{(2) Subjek Penelitian}

Subjek penelitian adalah followers akun Fahrida Inayati. Populasi dalam penelitian ini adalah pengguna Instagram yang mengikuti akun @fahrida26 di Instagramyang berjumlah 16.6K followers. 
Peneliti menggunakan teknik purposive sampling yang mencangkup orang-orang yang diseleksi atas kriteria-kriteria tertentu yang dibuat oleh peneliti berdasarkan tujuan riset ( Kriyantono, 2010 p.158). Kriteria - kriteria dalam penelitian ini adalah:

(a) Followers akun @fahrida26.

(b) Responden berusia 18-21 tahun.

(c) Minimal 3 bulan sudah mengikutiakun @ fahrida26.

Metode penelitian yang digunakan adalah internet survey. Menurut Valerie M. Sue (Sue, 2007, p.12) beberapa keuntungan survei yang dilakukan melalui internet adalah:

(a) Kecepatan (speed) Apabila anda menyebarkan di website yang populer, sebuah kuesioner berpotensi untuk mendapat ratusan respon dalam hitungan jam.

(b) Audiens yang luas Anda dapat menyebarkan tautan survei anda pada beberapa website dengan ijin dan kerjasama dari pemilik web tersebut. Ini dapat memperluas dan memperbanyak audiens anda.

(c) Ekonomis Survey melalui web adalah metode survei yang paling ekonomis jika dibandingkan dengan kemampuan data dan responden yang di dapat, yang mungkin saja terpisah secara geografis. Apalagi, dengan kemampuan dapat diisi sendiri oleh responden, mampumengurangi biaya untuk memasukkan data.

(d) Penambahan konten pendukung Jika diperlukan, peneliti dapat menambahkan gambar, video, dan sebagainya untuk mendukung survei.

(e) Kemampuan untuk menanyakan hal yang sensitif Survei melalui web sama seperti beberapa metode survei lain yang mampu diisi sendiri olehresponden, sehingga responden atau partisipan tidak berhadapanlangsung dengan peneliti.

(f) Privasi yang terjaga Apabila tidak dibutuhkan, responden tidak perlu memasukkan alamat email, nomor telepon, dan data diri lainnya sehingga privasi lebih terjaga.

\section{(3) Analisis Data}

(a) Pengeditan (editing) Pengeditan merupakan proses pengecekan dan penyesuaian yang diperlukan terhadap data penelitian yaitu untuk memudahkan proses pemberian kode dan pemrosesan data melalui teknik statistik. Editing adalah upaya untuk menghindari kesalahan, pengecekan kelengkapan pengisian kuisioner atau relevansi jawaban, keterbatasan tulisan, dan kejelasan makna serta menelaah kesiapan dalam suatu proses pencatatan. Tujuan pengeditan data penelitian merupakan jaminan kelengkapan, konsistensi dan kesiapan data penelitian dalam proses analisis.

(b) Pemberian kode (Koding) Untuk mengumpulkan data responden menggunakan kuesioner yang dalam penyusunannya menggunakan skala Likert. Peneliti menggunakan skala Likert karena berhubungan dengan pernyataan responden mengenai tingkat setuju atau tidak setuju mengenai berbagai pernyataan tentang perilaku, objek, orang atau kejadian (Kuncoro, 2003, p.157). Untuk mengukur, kategori-kategori motif dan kepuasan akan diberikan skor menggunakan skala sikap Likert dengan menggunakan lima alternatif jawaban. Scoring dilakukan dengan cara menentukan skor dari tiap item kategori dari tiaptiap kuesioner sehingga diperoleh skor total dari setiap kuesioner yang diisi olah masingmasing responden. Skor-skor penilaian dalam tiap item yaitu :

1) Untuk jawaban sangat setuju 5

2) Untuk jawaban setuju 4

3) Untuk jawaban netral 3

4) Untuk jawaban tidak setuju 2

5) Untuk jawaban sangat tidak setuju 1

(c) Analisis Deskriptif 
1) Frequencies Digunakan untuk menampilkan dan mendeskripsikan data yang terdiri atas satu variabel juga untuk menggambarkan penyebaran data yang berasal dari kuisioner.

2) Mean (Nilai rata-rata) Mean adalah nilai tengah dari total bilangan yang digunakan untuk mengetahui motif yang paling menonjol pada penggunaan salah satu akun Instagram yang akan diamati. Dari hal ini dapat dilihat bahwa hasil yang akan diharapkan adalah mean yang paling tinggi dan yang paling rendah saat muncul dalam frekuensi.

3) Interval kelas Untuk menentukan kelas katagori dari nilai yang di dapat baik dari perolehan nilai motif maupun dari kepuasan. Untuk menentukan besarnya kelas dari opini tersebut akan digunakan rumus sebagai berikut :

$\mathrm{c}=\left(\mathrm{X}_{\mathrm{n}}-\mathrm{X}_{1}\right) \mathrm{k}^{-1}$

Keterangan :

c : Perkiraan besarnya kelas

$\mathrm{k}$ : Banyaknya kelas

$\mathrm{X}_{\mathrm{n}}$ : Nilai observasi

$\mathrm{X}_{1}$ : Nilai observasi terkecil

(Supranto, 2000, p.64).

4) Tabulasi Silang (Crosstab)

Tabulasi silang atau Crosstab adalah sebuah tabel silang yang terdiri dari satu baris atau lebih, dan dalam bentuk satu kolom atau lebih. Analisis tabulasi silang pada prinsipnya menyajikan data dalam bentuk tabulasi yang meliputi baris dan kolom dan data untuk penyajian crosstab adalah data berskala nominal atau kategori.

\section{(D) Temuan Data}

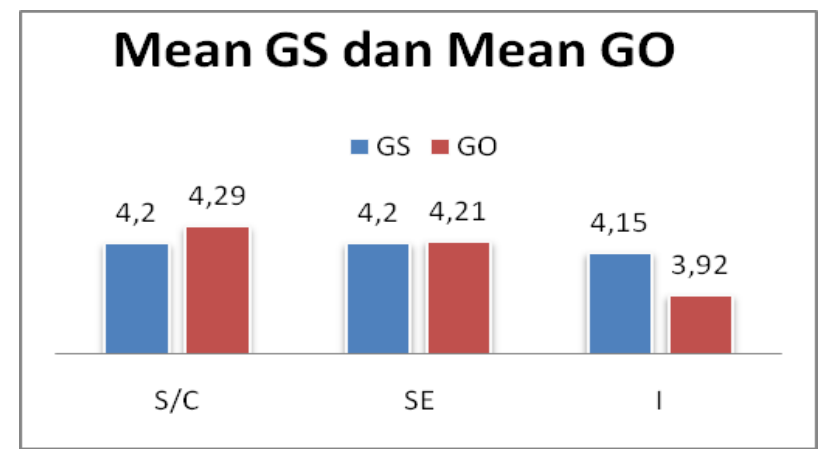

Gambar 2. Total Mean GS dan GO

Berdasarkan gambar di atas nilai mean setiap indikator. Indikator Sharing Communication adalah indikator yang paling tinggi nilai motif dan kepuasanya dengan jumlah nilai motif 4.20 dan nilai kepuasan 4.29. Oleh karena itu indikator Sharing Communication adalah motif dan kepuasan followers dalam mengikuti Fahrida Inayati di Instagram.

\section{(E) Analisis dan Interpretasi}

Berdasarkan hasil penelitian ini ditemukan bahwa indikator pertama tertinggi adalah indikator motif sharing communication rata-rata mean sebesar 4.20 dan indikator tertinggi kepuasan sharing communication rata-rata mean sebesar 4.29, kemudian pada motif dan kepuasan memiliki rata-rata mean yang berbeda. dari wawancara terbuka oleh peneliti terhadap responden atau followers Fahrida Inayati yaitu Rizka Yanti pada bagian motif pada Indikator sharing communication menyatakan bahwa anyageraldine adalah seseorang memberikan penampilan yang apa adanya sesuai dengan kehidupan sehari-harinya, membuat responden dalam penelitian ini sangat tertarik untuk mengikuti konten yang disajikan relevan dengan saya yang suka dengan hal-hal kekinian. 
Dari hasil temuan indikator motif sharing communication dapat dikaitkan dengan fenomena penelitian ini yaitu fenomena Selebgram di kalangan followers karena mereka memiliki latar belakang kehidupan yang berbeda-beda Fahrida Inayati sangat aktif di media sosial Instagram dengan memposting foto, video ataupun snapgram setiap harinya yang bertujuan menceritakan segala kegiatannya kepada followersnya Zarkasyi, (2013 p.95).

\section{(F) Simpulan}

Berdasarkan hasil penelitian ini untuk motif dan kepuasan, indikator yang mendapat nilai tertinggi adalah indikator sharing communication, hal ini sesuai dengan media sosial Instagram yang sering kali di gunakan sebagai tempat untuk berbagi informasi serta berinteraksi dengan orang lain dan juga lebih mengenal dengan sesama penggunanya melalui foto dan video yang diposting.

Melihat data perbandingan statistik antara 3 indikator terhadap GS dan GO, indikator sharing communication dan social escape mendapat hasil GO lebih tinggi dari jumlah GS sedangkan indikator information mendapat hasil sebaliknya GS lebih tinggi dari GO. Terlihat dari fenomena yaitu Fahrida Inayati adalah seseorang yang memiliki banyak penggemar atau followers dikarenakan foto atau video yang di upload olehnya menarik dan banyak disukai oleh para followers di instagram dan menjadi viral, perbincangan para netizen. Hal ini yang dapat memacu motivasi responden untuk mengikuti akun @ fahrida26 serta mengetahui post yang dibagikannya.

\section{(G) Referensi}

Ash-shiddieq, Fahri N. T. (2014). Pengaruh Celebrity Endorser Valentino Rossi terhadap Brandimage.

Alga Wibisono 19 Februari 2019 Biodata Fahrida Inayati, Selebgram yang Kepergok Dugem Bareng Bibi Ardiansyah Kekasih Vanessa Angel Rectrieved 24 Februari 2019 fromhttp://jatim.tribunnews.com/2019/02/19/biodata-anya-geraldine-selebgramyang-kepergokdugem-bareng-bibi-ardiansyah-kekasih-vanessa-angel.

Kriyantono, Rachmat (2010). Teknis Praktis Riset Komunikasi. Jakarta: Kencana. Monks, 2009. Tahap Perkembangan Masa Remaja. Medical Journal New Jersey.

McQuail, Denis. (2011). Teori Komunikasi Massa. Jakarta: Salemba Humanika.

M Nisrina. (2015). Bisnis Online, Manfaat Media Sosial Dalam Meraup Uang. Yogyakarta; Kobis.

Nurudin. (2013). Pengantar Komunikasi Massa. Jakarta : PT. Raja Grafindo Persada.

Nasrullah, Rulli. (2015). Media Sosial Perspektif Komunikasi, Budaya dan Sosioteknologi. Bandung: Simbiosa Rekatama Media.

Palmgreen, Philip. (1985). Uses and Gratifications: A Theoretical Perspective.

Ruggiero, Thomas E. (2000). Uses and gratifications theory in the 21st century mass communicatio \& society 3(1), 3-37: University of Texas at El Paso.

Sarwono, S. (2011) Psikologi Remaja. Jakarta: PT. Raja Grafindo.

Sue, Valerie M., \& Ritter, Lois A (2007). Conducting Online Survey Amerika: Sage Publication. 